\title{
Pengembangan media tes fisika berbasis online untuk sekolah menengah atas
}

\section{Bayu Fitra Prisuna*}

Fakultas Tarbiyah dan Ilmu Keguruan, Institut Agama Islam Negeri Pontianak Jalan Letjend Suprapto, Benua Melayu Darat, Kota Pontianak, Kalimantan Barat 78113, Indonesia

*Corresponding Author. e-mail: bayufitraprisuna@iainptk.ac.id

\begin{abstract}
Abstrak
Penilaian merupakan proses penting dalam pembelajaran, karena dengan penilaian, guru dapat mengetahui tingkat pemahaman dan kompetensi peserta didik pada materi dan dalam jangka waktu tertentu. Penelitian ini bertujuan untuk mengetahui efektivitas pelaksanaan media tes fisika berbasis online yang telah dikembangkan dengan model pengembangan 4-D serta mengetahui kualitas tes melalui pengembangan instrumen menggunakan analisis ITEMAN. Metode penelitian ini adalah penelitian dan pengembangan. Sampel uji coba terbatas terhadap peserta didik di Sekolah Madania Makassar sebanyak 10 orang dan sampel uji coba luas merupakan peserta didik kelas XI IPA 5 di SMAN 4 Makassar sebanyak 35 orang. Reliabilitas instrumen tes fisika berbasis online yang dianalisis dengan ITEMAN sebesar 0,734, di mana telah menghasilkan 20 butir soal dari 38 butir soal yang dinyatakan valid. Hasil penelitian menunjukkan bahwa respon peserta didik terhadap pelaksanaan media tes fisika berbasis online sebesar $40 \%$ dan berada dalam kategori baik. Sedangkan $60 \%$ berada dalam kategori sangat baik. Seluruh guru fisika di SMAN 4 Makassar yakni sebanyak 6 orang $(100 \%)$ memberikan respon sangat baik terhadap pelaksanaan media tes fisika berbasis online.
\end{abstract}

Kata Kunci: tes fisika online, efektivitas, kualitas

\section{Media development of online-based physics test for senior high school}

\begin{abstract}
Assessments are an important process in learning, because with judgment, teachers can know the level of understanding and competency of learners on the material and within a certain period. This research aims to determine the effectiveness of the implementation of media-based physics test that has been developed with 4-D development model as well as know the quality test through instrument development using ITEMAN analysis. This method of research is research and development. The test samples were limited to students at Madania Makassar School for 10 people and the extensive test samples were students of the XI IPA 5 class at SMAN 4 Makassar as much as 35 people. The reliability of online physics-based test instruments is analyzed by ITEMAN for 0.734, where it has produced 20 items of 38 items that are declared valid. The results showed that the student's response to the media implementation of online based physics tests amounted to $40 \%$ and is in good category. While $60 \%$ are in very good category. All teachers of physics at SMAN 4 Makassar, 6 people (100\%) provides excellent response to the implementation of media-based physics test online.
\end{abstract}

Keywords: online physics test, effectiveness, quality

How to Cite: Prisuna, B. F. (2020). Pengembangan media tes fisika berbasis online untuk sekolah menengah atas. Jurnal Penelitian Ilmu Pendidikan, 13(1), 42-52. doi:https://doi.org/10.21831/jpipfip.v13i1.30167.

Received 12-02-2020; Received in revised from 24-02-2020; Accepted 09-03-2020

This is an open-access article under the $\underline{\mathrm{CC}-\mathrm{BY}-\mathrm{SA}}$ license.

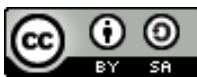

\section{PENDAHULUAN}

Perkembangan ilmu pengetahuan dan teknologi yang memanfaatkan teknologi komputer dan internet memungkinkan peningkatkan mutu pendidikan yang lebih baik. Perkembangan teknologi yang dinamis mendorong peserta didik untuk mengikuti dan memanfaatkannya secara tepat. Peranan 
teknologi juga sangat diharapkan karena dalam pelaksanaan kurikulum di setiap satuan pendidikan diharapkan dapat dilaksanakan dengan menggunakan pendekatan multistrategi dan multimedia serta sumber belajar dan teknologi yang memadai (Suratno, 2012). Penilaian merupakan proses penting dalam pembelajaran, karena penilaian guru dapat mengetahui tingkat pemahaman dan kompetensi peserta didik pada materi dan dalam jangka waktu tertentu. Menurut peranan fungsionalnya dalam pembelajaran, penilaian/tes hasil belajar dibagi menjadi empat macam, yaitu: (1) Tes Formatif, (2) Tes Sumatif, (3) Tes Diagnostik, dan (4) Tes Penempatan (Purwanto, 2009). Tes formatif digunakan untuk mengetahui sejauh mana kemampuan peserta didik setelah mengikuti proses pembelajaran. Tes formatif dalam praktik pembelajaran dikenal sebagai ulangan harian.

Praktek di lapangan menunjukkan bahwa asesmen formatif yang dikembangkan guru saat ini belum bisa terlaksana secara optimal (Kusairi, 2012). Salah satu faktor kurang optimalnya pelaksanaan asesmen formatif adalah pengembangan instrumen, implementasi, dan analisis data-data tes formatif memerlukan waktu, sementara beban tugas guru sangat tinggi terutama yang sudah disertifikasi. Pada umumnya tidak banyak guru yang melakukan tes formatif dengan menggunakan media berbasis online. Menurut Gogri (2013), "ada dua hal yang menarik dari asesmen formatif berbasis komputer yaitu mampu memberikan balikan yang instan dan meringankan beban kerja guru". Di sisi lain peserta didik sangat memerlukan balikan yang cepat (Hatziapostolou \& Paraskakis, 2010).

Berdasarkan pengamatan ketika melakukan tryout online di beberapa sekolah ditahun 2016, terlihat respon peserta didik sangat antusias dan tertarik mengerjakan soal tes dengan media berbasis online. Peserta didik dapat menggunakan berbagai media online untuk melakukan tes, seperti: komputer, laptop, notebook, bahkan android. Selain itu hasil tes peserta didik bisa diinformasikan beberapa saat setelah tes dilakukan, hal ini membuat peserta didik tidak menunggu lama untuk mengetahui hasil tes mereka. Terkait dengan itu, pengembangan media tes berbasis online dapat dijadikan salah satu solusi alternatif bagi guru untuk melakukan tes formatif pada siswa.

Bellotti, F., et al. (2013) dalam penelitian berjudul: Assessment in and of Serios Games-An Overview, dari Gale Economic Education Humanities Social-Science mengemukakan dua tujuan pembelajaran dari tes berbasis komputer, yakni (1) menyenangkan dan menghibur, (2) mendidik dan menantang. Belloti, merekomendasikan agar di masa depan perlu peningkatan tes dan pengujian berbasis komputer. Penyelenggaraan tes berbasis komputer juga didukung oleh Menteri Kementerian Pendidikan dan Kebudayaan yang menyatakan bahwa pelaksanaan ujian nasional dengan sistem komputer atau computer based test (CBT) lebih fleksibel atau dinamis karena tidak harus terjadwal secara nasional pada waktu yang sama. Berkaitan dengan hal tersebut, Pusat Penilaian Pendidikan telah mengembangkan penyelenggaraan Ujian Nasional berbasis komputer dan telah diuji cobakan di dua sekolah Indonesia di luar negeri, yaitu Singapura dan Kuala Lumpur. Hasil uji coba tersebut menunjukkan bahwa ujian dengan menggunakan komputer memungkinkan untuk digunakan pada peserta didik di Indonesia (Puspendik, 2015).

Pada Kurikulum 2013 tidak ada mata pelajaran TIK. Bagi sekolah yang ingin mendaftarkan untuk UNBK akan mengalami kesulitan pada keahlian atau skill peserta didik dalam menjalankan komputer. Dari permasalahan tersebut maka peneliti berpikir untuk mengembangkan media tes berbasis online sebagai upaya pembiasaan diri sedini mungkin agar pada saat pelaksanaan UNBK peserta didik tidak merasa gugup. Pengembangan media tes berbasis online ini akan dilakukan pada peserta didik SMA Negeri kelas XI. Hal ini dikarenakan peserta didik kelas XI adalah calon peserta didik kelas XII yang akan mengikuti UNBK pada tahun berikutnya. Jika media tes berbasis online ini sering digunakan pada pelaksanaan formatif, maka peserta didik akan lebih siap menghadapi UNBK.

Berdasarkan latar belakang diatas, maka dilakukan penelitian pengembangan dengan judul "Pengembangan Media Tes Fisika Berbasis Online untuk Sekolah Menangah Atas" bertujuan untuk mengetahui prosedur pengembangan media tes berbasis online, efektivitas pelaksanaan media tes berbasis online, dan kualitas tes berbasis online.

\section{METODE}

Metode yang digunakan dalam penelitian ini adalah penelitian dan pengembangan. Dalam penelitian ini dikembangkan dua model pengembangan. Pertama, pengembangan media online dikembangkan dengan model 4-D (Four D Model). Model ini dikembangkan oleh S. Thiagarajan, Dorothy S. Semmel, \& Melvyn I. Semmel (1974). Model pengembangan 4-D terdiri empat tahap utama 
yaitu: Pendefinisian (Define), Perencanaan (Design), Pengembangan (Develop), dan Penyebaran (Disseminate). Tahap pendefinisian meliputi langkah-langkah sebagai berikut: analisis kebutuhan, analisis peserta didik, analisis tugas, analisis konsep. Tahap perancangan meliputi langkah-langkah sebagai berikut: penetapan konsep media tes fisika berbasis online, penyusunan kisi-kisi, perancangan awal. Tahap pengembangan meliputi langkah-langkah sebagai berikut: uji coba pengembangan produk (uji coba terbatas dan uji coba luas). Tahap penyebaran merupakan tahap akhir dari penelitian menggunakan model 4-D. Tahap penyebaran dilakukan untuk mempromosikan produk pengembangan agar bisa diterima pengguna, baik individu, suatu kelompok, atau sistem. Kedua, pengembangan tes fisika berbasis online dikembangkan dengan pengembangan instrumen meliputi pembuatan kisi-kisi, tahap validasi isi dilakukan oleh pakar dengan menggunakan lembar validasi sebagai penilaian dan memperoleh masukan serta saran oleh ahli yang kemudian akan dilakukan revisi, tahap validasi kriteria yaitu instrumen diujicobakan dan dianalisis dengan analisis ITEMAN. Analisis ITEMAN menghasilkan tingkat kesukaran, daya beda, efektivitas pengecoh, dan reliabilitas. Subjek penelitian ini adalah 10 peserta didik di Sekolah Madania Makassar untuk dilakukan uji coba terbatas dan 35 peserta didik di SMAN 4 Makassar untuk dilakukan uji coba luas. Metode dan model ini dipilih karena bertujuan untuk menghasilkan produk berupa media tes fisika berbasis online.

Teknik pengumpulan data dalam penelitian ini adalah teknik tes dan nontes, yaitu pengumpulan data yang dilakukan selama proses penyusunan instrumen penilaian serta dalam proses penilaian pembelajaran di kelas, antara lain: menguji kelayakan media tes fisika berbasis online yang dibuat dengan membuktikan validitas isi oleh expert judgement, melakukan uji coba terbatas dan luas media tes fisika berbasis online kepada peserta didik untuk melihat hasil tes peserta didik, melihat respon guru dan peserta didik terhadap penggunaan media tes fisika berbasis online melalui pengisian angket, melakukan dokumentasi berupa data nilai hasil tes peserta didik.

\section{HASIL DAN PEMBAHASAN}

\section{Hasil}

\section{Prosedur Pengembangan Media Tes Fisika Berbasis Online}

Penelitian ini dilakukan berdasarkan model 4-D (four-D models) menurut Thiagarajan, yakni melalui tahap pendefinisian (define), perancangan (design), pengembangan (develop), dan penyebaran (disseminate).

Pada tahap define (pendefinisian) dilakukan analisis kebutuhan, analisis peserta didik, analisis tugas, dan analisis konsep. Pada analisis kebutuhan hasil wawancara diperoleh informasi bahwa pelaksanaan USBK \& UNBK tidak cocok dengan Kurikulum 2013 yang tidak terdapat mata pelajaran TIK (Teknologi, Informasi, dan Komunikasi) maka dari itu media tes fisika berbasis online yang kami kembangkan sangat dibutuhkan bagi peserta didik untuk mempersiapkan diri sedini mungkin dalam menghadapi USBK \& UNBK kedepannya.

Pada analisis peserta didik hasil observasi media tes fisika berbasis online ini perlu disesuaikan dengan karakteristik peserta didik Kelas XI di SMAN 4 Makassar. Pada tahap ini peneliti menganalisis karakteristik peserta didik yang pada umumnya hampir semua peserta didik memiliki android dan bahkan menjadi salah satu kebutuhan primer. Pada analisis tugas dilakukan analisis kompetensi inti dan kompetensi dasar materi Gelombang Bunyi tentang Efek Doppler. Selanjutnya disusun indikator ketercapaian pembelajaran. Aspek kognitif sebagai dasar pembuatan kisi-kisi soal. Pada analisis konsep peneliti menggunakan materi Gelombang Bunyi tentang Efek Doppler sebagai materi acuan dalam mengembangkan soal.

Tahap selanjutnya ialah design (perancangan). Pada tahap ini merupakan tahap perancangan instrumen yang akan digunakan pada materi Gelombang Bunyi tentang Efek Doppler. Tahap ini, peneliti melakukan konsultasi dengan dosen pembimbing untuk mendapatkan instrumen media tes fisika berbasis online yang digunakan untuk proses kegiatan tes formatif peserta didik sebelum divalidasi. Berdasarkan hasil pada proses define, ditetapkan media yang digunakan untuk membuat desain adalah menggunakan Adobe Dreamwever untuk membuat programnya yang berbasis PHP, sedangkan untuk membuat database nya menggunakan MySql dari program XAMPP yang berfungsi juga sebagai local server dan system Bootstrap untuk tampilannya. Selanjutnya, ditetapkan konsep media tes fisika berbasis online. Pengembangan media tes fisika berbasis online ini akan dilakukan dengan model terkontrol (controlled mode) artinya peserta didik bisa mengikuti tes formatif setelah 
didaftarkan oleh server dan diberikan sebuah username dan password, yang akan digunakan untuk log in. Setelah itu peserta didik dapat mengerjakan tes formatif berupa pilihan ganda dengan media komputer atau android melalui koneksi wifi yang terhubung ke server, setelah peserta didik selesai mengerjakan tes formatif akan muncul secara otomatis nilai hasil formatif yang telah dikerjakan, pengajar sebagai server juga dapat langsung melihat nilai peserta didik karena telah terinput secara otomatis ke database.

Proses pembuatan soal diawali dengan penyusunan kisi-kisi soal untuk menentukan ruang lingkup soal dan digunakan sebagai petunjuk penyusunan soal. Selanjutnya diawali dengan menentukan indikator ketercapaiannya seperti pada tabel analisis tugas. Butir soal yang dibuat berdasarkan pada ranah kognitif meliputi C1 (Mengingat), C2 (Memahami), C3 (Mengaplikasikan), dan C4 (Menganalisis).

Selain itu, dilakukan pembuatan angket. Sebelum proses pembuatan angket, diawali dengan penyusunan kisi-kisi untuk menentukan ruang lingkup angket dan digunakan sebagai petunjuk penyusunan pertanyaan-pertanyaan pada lembar angket respon peserta didik terhadap efektivitas pelaksanaan media tes fisika berbasis online.

Perancangan awal media terdiri dari pembuatan instrumen soal, instrumen angket respon peserta didik dan guru, pembuatan media tes fisika berbasis online berdasarkan konsep yang telah disusun oleh peneliti dan pembuatan lembar validasi. Media yang telah direvisi berdasarkan masukan dari dosen pembimbing kemudian dinilai oleh ahli. Ahli juga memberi masukan dan saran terhadap media dan soal. Validasi meliputi validasi soal, media, dan angket respon.

Tahap ketiga adalah develop (pengembangan). Tujuan tahap ini adalah untuk menghasilkan seluruh perangkat penelitian yang sudah direvisi berdasarkan masukan dari para pakar setelah dilakukan uji coba. Instrumen media tes fisika berbasis online yang dikembangkan sebelum digunakan harus melalui tahap validasi yang bertujuan untuk memperbaiki pengembangan awal instrumen. Teknik validasi dengan cara pengujian validasi isi menggunakan lembar validasi sebagai penilaian dan memperoleh masukan serta saran oleh ahli yang kemudian akan dilakukan revisi. Tahap validasi dilakukan dengan menyerahkan kisi-kisi instrumen, instrumen tes, dan lembar validasi instrumen. Adapun instrumen yang akan divalidasi oleh ahli, yaitu: instrumen soal, media, angket peserta didik dan angket guru.

Penilaian butir soal oleh validator berkenaan dengan valid atau tidaknya butir soal. Validator menilai butir soal yang dikembangkan oleh peneliti kemudian direvisi sesuai dengan saran sehingga dapat menjadi valid dan dapat dilanjutkan nantinya ke tahap validasi kriteria.

Penilaian media oleh validator berkenaan dengan layak atau tidaknya media untuk digunakan. Validator menilai media yang dikembangkan oleh peneliti kemudian direvisi sesuai dengan saran sehingga dapat menjadi layak dan dapat dilanjutkan nantinya ke tahap uji coba. Berdasarkan hasil perhitungan terlihat validitas isi lebih besar dari 0,75 , maka dapat diambil kesimpulan bahwa instrumen dinyatakan telah memenuhi validitas isi dan layak untuk dipergunakan. Sebelum dilakukan uji coba peneliti merevisi sesuai saran yang diberikan oleh validator.

Penilaian instrumen angket oleh validator berkenaan dengan valid atau tidaknya instrumen angket untuk digunakan. Validator menilai instrumen angket yang dikembangkan oleh peneliti kemudian direvisi sesuai dengan saran sehingga dapat menjadi valid dan dapat dilanjutkan nantinya ke tahap uji coba. Tahap uji coba meliputi tahapan uji coba terbatas dan tahapan uji coba luas. Angket disusun berdasarkan kriteria efektivitas dan indikator yang telah ditetapkan pada saat proses penyusunan. Berdasarkan hasil perhitungan terlihat validitas isi lebih besar dari 0,75, maka dapat diambil kesimpulan bahwa instrumen dinyatakan telah memenuhi validitas isi dan bisa dipergunakan. Sebelum dilakukan uji coba peneliti merevisi sesuai saran yang diberikan oleh validator.

Penilaian instrumen angket oleh validator berkenaan dengan valid atau tidaknya instrumen angket untuk digunakan. Validator menilai instrumen angket yang dikembangkan oleh peneliti kemudian direvisi sesuai dengan saran sehingga dapat menjadi valid dan dapat dilanjutkan nantinya ke tahap uji coba. Tahap uji coba meliputi tahapan uji coba terbatas dan tahapan uji coba luas. Angket disusun berdasarkan kriteria efektivitas dan indikator yang telah ditetapkan pada saat proses penyusunan. Berdasarkan hasil perhitungan terlihat validitas isi lebih kecil dari 0,75 maka dapat diambil kesimpulan bahwa instrumen dinyatakan belum memenuhi validitas isi dan instrumen dapat dipergunakan dengan beberapa perbaikan atau revisi. 
Tahap validasi kriteria dilakukan terhadap instrumen tertentu seperti instrumen soal. Tahap ini dilakukan setelah tahap validasi ahli selesai dilakukan, bertujuan mengetahui butir-butir soal yang valid dan drop sebelum akhirnya di input ke dalam media tes fisika berbasis online. Tahap ini melibatkan 36 peserta didik dari Kelas XI IPA 3 untuk mengerjakan soal sebanyak 38 butir soal pilihan ganda materi Gelombang Bunyi tentang Efek Doppler. Data yang didapatkan berupa skor dikotomi (0 dan 1), maka untuk menghitung korelasi antara skor butir dengan skor total instrumen digunakan korelasi point biserial ( $\mathrm{r}_{\mathrm{pbis}}$ ) dan dianalisis dengan bantuan program Ms. Excel.

Setelah dilakukan validasi ahli kemudian dilakukan uji coba terbatas dengan menguji cobakan media tes fisika berbasis online. Uji coba ini melibatkan 10 peserta didik di Sekolah Madania Makassar. Peserta didik melakukan tes formatif menggunakan media tes fisika berbasis online dan akan diperoleh nilai dari tes tersebut. Setelah selesai mengerjakan, selang waktu 30 menit peserta didik diberi angket untuk mengetahui respon setelah menggunakan media tes fisika berbasis online. Hasil diperoleh digunakan sebagai bahan revisi untuk mendapatkan instrumen yang lebih baik. Selanjutnya dilakukan uji coba luas terhadap media tes fisika berbasis online pada subjek penelitian yaitu 35 peserta didik Kelas XI IPA 5 di SMAN 4 Makassar setelah revisi uji coba terbatas. Teknis pelaksanaan uji coba luas sama dengan uji coba terbatas.

Tahap disseminate merupakan tahap akhir dari penelitian menggunakan model 4-D. Pada tahap ini dilakukan penyebaran instrumen media tes fisika berbasis online yang dikembangkan. Tes fisika berbasis online yang telah dikembangkan sampai kegiatan uji coba produk dan telah direvisi, selanjutnya diterapkan pada peserta didik kelas lain selain kelas subjek penelitian di sekolah yang sama atau di sekolah berbeda. Tujuan kegiatan ini untuk melihat keefektifan dari aplikasi tes fisika berbasis online sebagai sarana evaluasi pembelajaran. Beberapa menu utama pada halaman admin terlihat sebagai berikut:

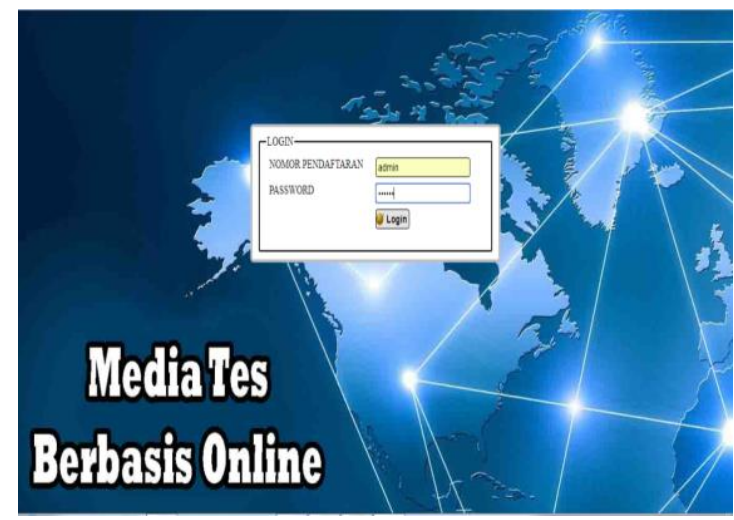

Gambar 1. Halaman log in admin

Pada Gambar 1. menunjukkan halaman log in yang diisi oleh admin atau server.

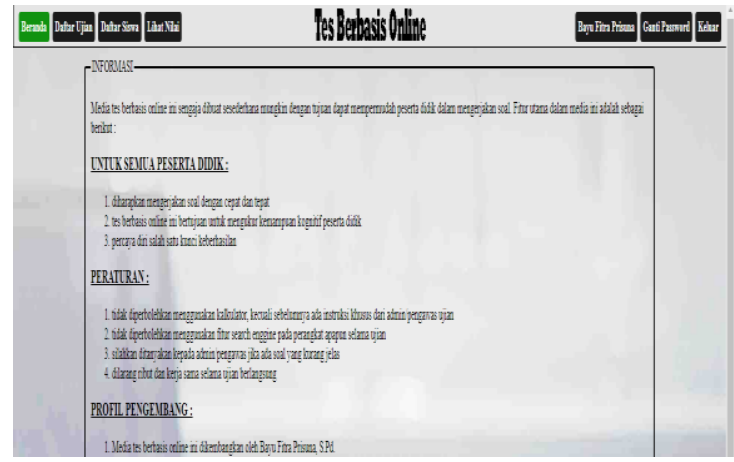

Gambar 2. Menu beranda admin

Pada Gambar 2. menunjukkan menu beranda yang berisi tentang informasi dan aturan secara keseluruhan yang harus diperhatikan oleh peserta didik serta profile pengembang media yaitu admin. 




Gambar 3. Menu daftar ujian

Pada Gambar 3. menunjukkan menu daftar ujian yang berisi pilihan mata pelajaran yang dapat ditambahkan untuk dijadikan sebagai tes formatif. Pada menu ini admin juga dapat mengisi keterangan yang berkaitan dengan tes formatif yang akan dilaksanakan.

\section{Efektivitas Pelaksanaan Media Tes Fisika Berbasis Online}

Setelah dilakukan validasi isi oleh ahli dan dinyatakan valid kemudian dilakukan uji coba terbatas dan uji coba luas untuk mengetahui efektivitas pelaksanaan media tes fisika berbasis online yang telah dikembangkan. Peserta didik yang telah selesai tes formatif dengan menggunakan media tes fisika berbasis online pada kegiatan uji coba terbatas dan uji coba luas. Selanjutnya peneliti menyiapkan angket respon yang akan diberikan selang waktu 30 menit. Pertanyaan-pertanyaan pada angket respon peserta didik dan guru disusun berdasarkan kriteria efektivitas yaitu: kualitas, kepraktisan, dan kepuasan.

Uji coba terbatas melibatkan 10 peserta didik di Sekolah Madania Makassar. Peserta didik melakukan tes formatif menggunakan media tes fisika berbasis online dan diperoleh nilai dari tes tersebut. Setelah selesai mengerjakan, selang waktu 30 menit peserta didik diberi angket untuk mengetahui respon setelah menggunakan media tes fisika berbasis online. Hasil diperoleh digunakan sebagai bahan revisi untuk mendapatkan instrumen yang lebih baik. Berdasarkan uji coba terbatas, diperoleh data distribusi frekuensi respon peserta didik terhadap efektivitas pelaksanaan media tes fisika berbasis online pada dimensi kualitas dilihat pada Tabel 1.

Tabel 1. Distribusi Frekuensi dan Persentase Respon Peserta Didik terhadap Efektivitas Pelaksanaan Media Tes Fisika Berbasis Online pada Dimensi Kualitas

\begin{tabular}{cccc}
\hline \multirow{2}{*}{ Rentang } & \multirow{2}{*}{ Kategori } & \multicolumn{2}{c}{ Uji Coba Terbatas } \\
\cline { 3 - 4 } & & Frekuensi & Persentase (\%) \\
\hline $21-25$ & Sangat Baik & 2 & 20,0 \\
$16-20$ & Baik & 7 & 70,0 \\
$11-15$ & Kurang & 1 & 10,0 \\
$6-10$ & Sangat Kurang & 0 & 0,0 \\
\hline \multicolumn{2}{c}{ Jumlah } & 10 & 100 \\
\hline
\end{tabular}

Berdasarkan Tabel 1 terlihat hasil respon peserta didik terhadap efektivitas pelaksanaan media tes fisika berbasis online pada dimensi kualitas, di asumsikan bahwa rentang skor 6-10 (sangat kurang), 1115 (kurang), 16-20 (baik), 21-25 (sangat baik). Dari total 10 peserta didik, 10\% (1 orang) merespon kurang baik, $70 \%$ (7 orang) merespon baik, dan 20\% (2 orang) merespon sangat baik. Data menunjukkan pelaksanaan media tes berbasis online cenderung memiliki kualitas baik.

Langkah selanjutnya dilakukan uji coba luas terhadap terhadap media tes fisika berbasis online pada subjek penelitian yaitu 35 peserta didik Kelas XI IPA 5 di SMAN 4 Makassar. Teknis pelaksanaan uji coba luas sama dengan uji coba terbatas. Berdasarkan hasil uji coba luas, diperoleh data distribusi frekuensi respon peserta didik terhadap efektivitas pelaksanaan media tes fisika berbasis online pada dimensi kualitas dilihat pada Tabel 2. 
Jurnal Penelitian Ilmu Pendidikan,13 (1), 2020 - 47

Prisuna

Tabel 2. Distribusi Frekuensi dan Persentase Respon Peserta Didik terhadap Efektivitas Pelaksanaan Media Tes Berbasis Online pada Dimensi Kualitas

\begin{tabular}{cccc}
\hline \multirow{2}{*}{ Rentang } & \multirow{2}{*}{ Kategori } & \multicolumn{2}{c}{ Uji Coba Luas } \\
\cline { 3 - 4 } & & Frekuensi & Persentase (\%) \\
\hline $21-25$ & Sangat Baik & 4 & 11,1 \\
$16-20$ & Baik & 30 & 83,3 \\
$11-15$ & Kurang & 2 & 5,6 \\
$6-10$ & Sangat Kurang & 0 & 0,0 \\
\hline \multicolumn{2}{c}{ Jumlah } & 36 & 100 \\
\hline
\end{tabular}

Berdasarkan Tabel 2. terlihat hasil respon peserta didik terhadap efektivitas pelaksanaan media tes fisika berbasis online pada dimensi kualitas, diasumsikan bahwa rentang skor 6-10 (sangat kurang), 11-15 (kurang), 16-20 (baik), 21-25 (sangat baik). Dari total 36 peserta didik, 5,6\% (2 orang) merespon kurang baik, 83,3\% (30 orang) merespon baik, dan 11,1\% (4 orang) merespon sangat baik. Data menunjukkan pelaksanaan media tes fisika berbasis online cenderung memiliki kualitas baik.

\section{Kualitas Tes Fisika Berbasis Online}

Sebelum digunakan instrumen pendukung dalam penelitian ini terlebih dahulu divalidasi oleh pakar. Selanjutnya data hasil validasi pakar dikumpul dan dianalisis untuk mengetahui instrumen telah valid atau tidak. Untuk menganalisis validitas instrumen yang telah dikembangkan untuk menentukan validitas isi secara keseluruhan dari suatu tes melalui penilaian pakar. Relevansi kedua pakar secara menyeluruh merupakan validitas isi Gregory, yaitu berupa koefisien validitas isi. Berdasarkan perhitungan tersebut, diperoleh validitas isi 0,87 maka instrumen tes dinyatakan valid.

Hal selanjutnya yang dilakukan adalah analisis kuantitatif. Analisis kuantitatif dilakukan dengan menampilkan karakteristik butir setiap soal atau item berdasarkan teori tes klasik. Analisis ini dilakukan dengan menggunakan bantuan program komputer. Selanjutnya digunakan Teori Tes Klasik untuk menganalisis soal. Analisis berdasarkan teori ini berupa analisis tes yang mencakup tingkat kesukaran, daya beda, efektivitas pengecoh, dan reliabilitas. Analisis ini pada penerapanya menggunakan bantuan program Item and Tes Analysis (ITEMAN) version 3.0.

Setelah instrumen divalidasi oleh pakar, selanjutnya dilakukan validasi kriteria, yaitu instrumen diujicobakan dan dianalisis dengan analisis item. Analisis item dilakukan dengan menghitung korelasi antara skor butir instrumen dengan skor total. Hasil analisis validasi kriteria dari 38 butir soal menghasilkan 20 butir soal yang valid dan 18 butir soal yang di drop. Setelah mendapatkan butir soal yang valid maka selanjutnya butir soal dianalisis dengan menggunakan program ITEMAN Version 3.0. untuk menampilkan karakteristik butir setiap soal atau item berdasarkan teori tes klasik. Analisis berdasarkan teori ini berupa analisis tes yang mencakup tingkat kesukaran, daya beda, efektifitas pengecoh, dan reliabilitas.

Analisis tingkat kesukaran dari 38 butir soal menghasilkan 32 butir soal berada pada tingkat kesukaran sedang, dan 6 butir soal berada pada tingkat kesukaran mudah. Analisis daya beda dari 38 butir soal menghasilkan 13 butir soal berada pada kategori sangat baik, artinya soal diterima dan dapat digunakan dan 9 butir soal pada kategori baik, artinya soal diterima dan dapat digunakan, dan 4 butir soal pada kategori cukup, artinya soal diterima dan dapat digunakan dengan revisi, dan 12 butir soal pada kategori jelek, artinya soal tidak dapat digunakan atau dibuang. Butir tes yang berbentuk pilihan ganda hanya ada satu pilihan jawaban yang benar dan pilihan jawaban lainnya digunakan untuk pengecoh. Pilihan jawaban yang terbaik sebagai pengecoh adalah pilihan jawaban dalam suatu butir tes memiliki kemiripan atau kesetaraan antara yang satu dan lainnya. Tujuan dilakukannya analisis pengecoh atau distraktor pada tes pilihan ganda adalah mengetahui apakah semua pilihan jawaban telah dipilih oleh peserta tes. Jika terdapat pengecoh yang tidak dipilih oleh peserta didik, maka pengecoh tersebut tidak efektif atau keberadaan pengecoh tidak ada fungsinya.

Hasil olah data menunjukkan pada butir soal 2, 17, 22, 23, 24, 26, 28, 30 muncul keterangan "CHECK THE KEY D was specified, A works better" pada hasil analisis program ITEMAN itu artinya yang menunjukkan bahwa kunci jawaban D harus diperiksa kembali dan alternatif jawaban A tampak berfungsi lebih baik. Diasumsikan bahwa peserta tes yang pintar (skor totalnya tinggi) cenderung menjawab opsi A. 
Sifat reliabel dari sebuah alat ukur berkenaan dengan kemampuan alat ukur tersebut memberikan hasil yang konsisten dan stabil bila dilakukan pengukuran yag berulang dalam waktu yang berbeda pada objek yang sama. Kriteria reliabilitas yang digunakan dalam penelitian ini adalah apabila batas minimal suatu tes memiliki ajeg (konsisten dan stabil) adalah 0,70, sedangkan tidak reliabel apabila batas suatu tes $<0,70$. Hasil pengolahan data reliabilitas tes sebesar 0,734, maka instrumen tes dinyatakan telah reliabel.

\section{Pembahasan}

Dalam penelitian ini menggunakan metode penelitian dan pengembangan (Research and Development). Metode penelitian (Research and Development) menurut Sugiyono (2012, 407) merupakan "metode penelitian yang digunakan untuk menghasilkan produk tertentu dan menguji keefektifan produk tersebut". Proses pengembangannya peneliti menggunakan model pengembangan 4D model yang terdiri dari 4 tahapan yaitu: tahap pendefinisian (define), perancangan (design), pengembangan (develop), dan penyebaran (disseminate) dengan harapan mengetahui sejauh mana efektivitas pelaksanaan media tes fisika berbasis online dan kualitas tes fisika berbasis online.

Berdasarkan permasalahan pada tahap pendefinisian yang telah dijelaskan bahwa tahap pendefinisian yang dilakukan peneliti meliputi langkah-langkah analisis kebutuhan, analisis peserta didik, analisis tugas, dan analisis konsep. Dalam hasil penelitian diketahui bahwa selain kebutuhan peserta didik akan pembiasaan penggunaan media tes fisika berbasis online pada ujian-ujian formatif, karakteristik peserta didik yang dominan menggunakan android dalam kesehariannya juga mendukung terlaksananya penelitian pengembangan media tes fisika berbasis online. Menurut guru fisika di SMAN 4 Makassar, pelaksanaan pengembangan media tes fisika berbasis online ini sangat berguna bagi peserta didik nantinya karena menjadi bahan pelajaran ketika tidak terlaksananya dengan baik proses USBN/BK pada kelas XII. Pada penelitian pengembangan ini peneliti menyusun soal berdasarkan KI dan KD materi Bunyi tentang Efek Doppler, dan konsep materi yang disusun lebih mudah peserta didik terapkan pada soal tes formatif nantinya karena peneliti juga mengajarkan secara lagsung dikelas kepada peserta didik mengenai konsep yang telah disusun berdasarkan KI dan KD yang menjadi acuan pembuatan soal tes formatif.

Setelah tahap pendefinisian maka peneliti melakukan tahap selanjutnya yaitu tahap perancangan. Pada tahap perancangan yang dilakukan peneliti meliputi langkah-langkah penetapan konsep media tes fisika berbasis online, penyusunan kisi-kisi instrumen, perancangan awal. Pada awal tahap ini ditetapkan konsep media tes fisika berbasis online adalah dalam pengembangan media tes fisika berbasis online ini akan dilakukan dengan model terkontrol (controlled mode) artinya peserta didik bisa mengikuti tes formatif setelah didaftarkan oleh server dan diberikan sebuah username dan password, yang akan digunakan untuk log in. Selanjutnya, proses pembuatan soal diawali dengan penyusunan kisi-kisi soal untuk menentukan ruang lingkup soal dan digunakan sebagai petunjuk penyusunan soal. Materi yang digunakan adalah Bunyi tentang Efek Doppler, kemudian diawali dengan menentukan indikator ketercapaiannya seperti pada tabel analisis tugas. Dari 38 Butir soal yang dibuat merujuk dari KI dan KD maka disebarlah pada ranah kognitif meliputi C1 (Mengingat), C2 (Memahami), C3 (Mengaplikasikan),dan C4 (Menganalisis). Begitu juga dengan kisi-kisi angket dari 18 butir pernyataan yang dibuat disebar berdasarkan aspek yang dikembangkan adalah aspek-aspek yang berhubungan dengan respon terhadap media tes fisika berbasis online yaitu: efektif, efesien, dan daya tarik. Selanjutnya pada tahap perancangan awal media terdiri dari pembuatan instrumen soal, instrumen angket respon peserta didik dan guru, pembuatan media tes fisika berbasis online berdasarkan konsep yang telah disusun oleh peneliti dan pembuatan lembar validasi. Pada tahap ini peneliti mengkonsultasikan semua instrumen yang digunakan pada saat penelitian kepada dosen pembimbing, adapun saran dan masukan dari dosen pembimbing menjadi bahan perbaikan sebelum pada akhirnya divalidasi oleh validator.

Kemudian pada tahap pengembangan akan menghasilkan seluruh perangkat penelitian yang sudah direvisi berdasarkan masukan dari para ahli setelah dilakukan uji coba. Dari semua instrumen penelitian yang telah melewati tahap penilaian pakar menghasillkan antara lain: instrumen soal dinyatakan valid, instrumen media dinyatakan valid, instrumen angket respon peserta didik dinyatakan valid, sedangkan instrumen angket respon guru dinyatakan belum memenuhi validasi isi akan tetapi dapat dipergunakan dengan beberapa perbaikan atau revisi. Setelah itu instrumen soal divalidasi kriteria, dari 38 butir soal yang di analisis menggunakan bantuan program Ms. Excel untuk menentukan rbis atau rhitung maka 
dihasilkan 20 butir soal dinyatakan valid dan 18 butir dinyatakan drop atau dibuang. Setelah itu untuk mengetahui karakteristik butir soal yang meliputi tingkat kesukaran, daya beda, efektifitas pengecoh, dan reliabilitas. Peneliti menggunakan bantuan program Item and Tes Analysis Version 3.00 (ITEMAN). Instrumen selanjutnya dilakukan uji coba terbatas bertujuan menghasilkan media yang lebih baik lagi. Dari hasil uji coba terbatas, $50 \%$ responden merasa media tes fisika berbasis online yang diterapkan sudah sangat baik, $40 \%$ responden merasa media tes fisika berbasis online yang diterapkan sudah baik, sedangkan $10 \%$ responden merasa media tes fisika berbasis online yang diterapkan kurang baik. Dari hasil tersebut peneliti memperbaiki yang menjadi kekurangan dari saran dan masukan yang diberikan responden. Setelah itu melanjutkan pada tahap uji coba luas, dari hasil uji coba luas persentase responden yang merasa pelaksanaan media tes ini sangat baik bertambah, yaitu $60 \%$ responden merasa media tes fisika berbasis online yang diterapkan sudah sangat baik sedangkan $40 \%$ responden merasa media tes fisika berbasis online yang diterapkan sudah baik. Asumsi bahwa media tes fisika berbasis online ini sudah sangat baik ditunjang oleh data respon guru terhadap media tes fisika berbasis online, yaitu $100 \%$ guru merasa media tes fisika berbasis online yang diterapkan sudah sangat baik.

Tahap disseminate merupakan tahap akhir dari penelitian menggunakan 4-D model. Pada tahap ini dilakukan penyebaran instrumen media tes fisika berbasis online yang dikembangkan. Tahap penyebaran dilakukan untuk mempromosikan produk pengembangan agar bisa diterima pengguna, baik individu, suatu kelompok, atau sistem. Diharapkan media tes fisika berbasis online ini telah sesuai dan dapat menjadi solusi bagi peserta didik untuk mempersiapkan diri sedini mungkin dalam menghadapi USBK dan UNBK. Dan diharapkan guru juga dapat mengadopsi sistem tes formatif berbasis online. Sejalan dengan yang disampaikan (Rosyani dkk., 2018) dalam penelitian berjudul: Training to Make Evaluation of Learning Media and Computer-based Exams using Ispring mengemukakan bahwa "Siswa harus dilatih dan dipersiapkan untuk mengikuti ujian dengan sistem online dimulai dari pemberian kuis ataupun dalam ulangan harian. Para guru juga harus dibekali ilmu bagaimana caranya membuat media evaluasi belajar online sendiri untuk mengembangkan pengetahuan dibidang teknologi sebelum mensosialisasikannya kepada anak didiknya".

Untuk mengetahui sejauh mana efektivitas pelaksanaan media tes fisika berbasis online yang telah dikembangkan. Peneliti menyusun angket respon peserta didik dan guru disusun berdasarkan kriteria efektivitas yaitu: kualitas, kepraktisan, dan kepuasan. Peserta didik yang telah selesai tes formatif dengan menggunakan media tes fisika berbasis online pada kegiatan uji coba terbatas dan uji coba luas, selanjutnya diberikan lembar angket yang berisikan pertanyaan-pertanyaan. Peneliti memberikan lembar angket tersebut dan menyampaikan pengisian dilakukan pada saat sebelum pulang sekolah dengan tujuan memberi interval waktu antara pelaksanaan tes menggunakan media tes fisika berbasis online dengan pengisian lembar angket supaya peserta didik bisa berpikir, memahami, dan mengingat kembali apa-apa yang dia rasakan pada saat pelaksaan tes.

Hasil uji coba terbatas dan uji coba luas yang telah dilakukan dalam penelitian menunjukkan bahwa pelaksanaan media tes fisika berbasis online adalah efektif. Uji coba terbatas melibatkan 10 peserta didik di Sekolah Madania Makassar. Pada dimensi kualitas, pelaksanaan media tes fisika berbasis online cenderung memiliki kualitas baik, terlihat dari data yang didapatkan bahwa dari total 10 peserta didik, $10 \%$ (1 orang) merespon kurang baik, $70 \%$ ( 7 orang) merespon baik, dan $20 \%$ (2 orang) merespon sangat baik. Dimensi kepraktisan, pelaksanaan media tes fisika berbasis online cenderung memiliki kepraktisan yang baik, terlihat dari total 10 peserta didik, 20\% (2 orang) merespon kurang baik, $60 \%$ (6 orang) merespon baik, dan 20\% (2 orang) merespon sangat baik. Pada dimensi kepuasan, pelaksanaan media tes fisika berbasis online cenderung memiliki kepuasan yang tinggi, terlihat dari total 10 peserta didik, $10 \%$ ( 1 orang) merespon rendah, 30\% (3 orang) merespon tinggi, dan 60\% (6 orang) merespon sangat tinggi. Selanjutnya pada uji coba luas melibatkan 35 peserta didik Kelas XI IPA 5 di SMAN 4 Makassar dilakukan setelah melakukan revisi pada uji coba terbatas. Dimensi kualitas pelaksanaan media tes fisika berbasis online cenderung memiliki kualitas yang baik, dari total 36 peserta didik, 5,6\% (2 orang) merespon kurang baik, 83,3\% (30 orang) merespon baik, dan 11,1\% (4 orang) merespon sangat baik. Dimensi kepraktisan, pelaksanaan media tes fisika berbasis online cenderung memiliki kepraktisan yang baik, terlihat dari total 36 peserta didik, 5,6\% (2 orang) merespon kurang baik, 66,6\% (24 orang) merespon baik, dan 27,8\% (10 orang) merespon sangat baik. Dimensi kepuasan, pelaksanaan media tes fisika berbasis online cenderung memiliki kepuasan yang tinggi, terlihat dari total 36 peserta didik, 13,9\% (5 orang) merespon rendah, 44,4\% (16 orang) merespon tinggi, dan 41,7\% (15 orang) merespon sangat tinggi. Asumsi mengenai efektifnya pelaksanaan media tes fisika berbasis 
online ini diperkuat dengan data respon dari guru, yaitu dari total 3 guru fisika SMA Negeri 4 Makassar dijadikan sebagai responden yang memberikan penilaian terhadap media tes fisika berbasis online yang dikembangkan. Dimensi kualitas pelaksanaan media tes fisika berbasis online cenderung memiliki kualitas yang baik, dari total 3 peserta didik, 66,7\% (2 orang) merespon baik, 33,3\% (1 orang) merespon sangat baik. Dimensi kepraktisan, pelaksanaan media tes fisika berbasis online cenderung memiliki kepraktisan yang baik, terlihat dari total 3 peserta didik, 100\% (3 orang) merespon sangat baik. Dimensi kepuasan, pelaksanaan media tes fisika berbasis online cenderung memiliki kepuasan yang tinggi, terlihat dari total 3 peserta didik, 100\% (3 orang) merespon sangat tinggi.

Untuk menghasilkan kualitas instrumen tes fisika berbasis online yang baik digunakan dalam penelitian terlebih dahulu instrumen divalidasi oleh pakar. Dalam penelitian ini dilakukan analisis validitas instrumen tes yang telah dikembangkan untuk menentukan validitas isi secara keseluruhan dari suatu tes melalui penilaian pakar. Relevansi kedua pakar secara menyeluruh merupakan validitas isi dengan uji Gregory, yaitu berupa validitas isi. Hasil penilaian instrumen soal oleh pakar dapat dilihat pada Tabel 4.12. Berdasarkan perhitungan dari validator 1 dan validator 2 , diperoleh validitas isi 0,87 maka instrumen tes dinyatakan valid.

Setelah instrumen divalidasi oleh pakar, selanjutnya dilakukan validasi kriteria, yaitu instrumen tes diujicobakan dan dianalisis dengan analisis item. Instrumen tes diujicobakan pada peserta didik kelas XI IPA 3 SMA Negeri 4 Makassar sebanyak 36 peserta didik. Analisis item dilakukan dengan menghitung korelasi antara skor butir instrumen dengan skor total. Menurut Ebel dan Frisbie (1991) dalam Essentials of Educational Measurement Kriteria baik tidaknya butir soal adalah bila korelasi point biserial: $>0.40=$ butir soal sangat baik; $0.30-0.39=$ soal baik, tetapi perlu perbaikan; $0.20-0.29=$ soal dengan beberapa catatan, biasanya diperlukan perbaikan; $<0.19=$ soal jelek, dibuang, atau diperbaiki melalui revisi. Dari 38 butir soal yang diujicobakan kemudian dianalisis menggunakan bantuan program exel maka dihasilkan 20 butir soal dinyatakan valid dan 18 butir soal dinyatakan drop atau dibuang.

Instrumen tes juga dianalisis menggunakan teori klasik yaitu program Item and Tes Analysis (ITEMAN) Version 3.0. Analisis ini dilakukan dengan menggunakan bantuan program komputer dan bertujuan untuk menampilkan karakteristik butir setiap soal atau item berdasarkan teori tes klasik yang mencakup: Tingkat kesukaran, daya beda, efektifitas pengecoh, realibilitas. Menurut Sudjana (2002) mengatakan bahwa terdapat tingkat kesukaran mudah, sedang dan sukar. Tingkat kesukaran yang baik adalah 0,25 sampai 0,75 . Soal yang mempunyai tingkat kesukaran di bawah 0,25 berarti soal itu sukar, sebaliknya soal yang mempunyai tingkat kesukaran di atas 0,75 adalah soal itu terlalu mudah. Hasil analisis menggunakan iteman menghasilkan 32 butir soal memiliki tingkat kesukaran sedang dan 6 butir soal memiliki tingkat kesukaran mudah. Menurut Arifin (2012:273), "perhitungan daya pembeda adalah pengukuran sejauh mana suatu butir soal dapat membedakan peserta didik yang sudah menguasai kompetensi dengan peserta didik yang belum menguasai kompetensi". Daya Pembeda dapat diketahui dengan melihat besar kecilnya indeks diskriminasi soal. Penentuan Daya Pembeda dapat menggunakan klasifikasi sebagai berikut: $\mathrm{D}=0,00-0,20=$ jelek (poor); $\mathrm{D}=0,21-0,40=$ cukup (satisfactory); $\mathrm{D}=$ $0,41-0,70=$ baik $(\mathrm{good}) ; \mathrm{D}=0,71-1,00=$ baik sekali $($ excellent $) ; \mathrm{D}=$ negatif, semuanya tidak baik. Jadi, sebaiknya dibuang (Arikunto, 2012). Hasil analisis menggunakan ITEMAN menghasilkan 13 butir soal memiliki indeks daya beda yang sangat baik, 9 butir soal memiliki indeks daya beda yang baik, 4 butir soal memiliki indeks daya beda yang cukup artinya butir soal diterima dengan revisi. 12 butir soal memiliki indeks daya beda yang jelek. Menurut Sudijono (2015) mengungkapkan bahwa pengecoh telah dapat menjalankan fungsinya dengan baik apabila pengecoh tersebut telah dipilih sekurang-kurangnya $5 \%$ dari seluruh peserta tes. Hasil analisis menggunakan ITEMAN menghasilkan 30 butir soal memiliki efektivitas pengecoh yang baik dan 8 butir soal memiliki efektivitas pengecoh yang tidak baik. Hasil analisis menggunakan iteman menghasilkan reliabilitas alpha sebesar 0.734 maka instrumen tes dinyatakan reliabel. "Secara teoritik besarnya koefisien reliabilitas berkisar mulai dari 0,0 sampai dengan angka 1,0 akan tetapi kenyataannya keofisien reliabilitas sebesar 1,0 praktis tidak pernah dijumpai" (Azwar, 2015: 13). Analisis menggunakan teori klasik sangat membantu dalam menganalisis instrumen tes karena mudah dalam penerapannya. Sebenarnya banyak versi ITEMAN akan tetapi Version 3.0. lebih mudah dalam menginterpretasikan hasil yang telah dianalisis sebelumnya oleh komputer. 


\section{PENUTUP}

Berdasarkan hasil penelitian dan pembahasan maka dapat ditarik simpulan bahwa prosedur pengembangan media tes fisika berbasis online dalam proses pengembangannya menggunakan model pengembangan 4-D yang meliputi 4 tahapan yaitu: tahap pendefinisian (define), perancangan (design), pengembangan (develop), dan penyebaran (disseminate). Telah diperoleh instrumen yang efektif dalam pelaksanaan media tes fisika berbasis online, hasil uji coba terbatas dan uji coba luas menunjukkan bahwa data memiliki kecenderungan baik pada dimensi kualitas, kepraktisan, dan kepuasan. Telah diperoleh instrumen soal pilihan ganda yang memiliki kualitas baik dan layak untuk digunakan dalam tes formatif Fisika materi Bunyi tentang Efek Doppler. Instrumen soal telah melalui tahap validasi isi oleh pakar dan dinyatakan valid, kemudian dilakukan tahap validasi kriteria dan dianalisis dengan Program ITEMAN Version 3.0. sehingga menghasilkan 20 butir soal yang valid.

\section{UCAPAN TERIMA KASIH}

Penulis mengucapkan rasa syukur kepada Allah SWT karena telah mempermudah segala urusan selama menjalani penelitian ini. Terima kasih kepada kedua orang tua atas doa dan dukungannya selama ini dan penulis juga mengucapkan terimakasih dengan kerendahan hati kepada Bapak Dr. Kaharuddin Arafah, M.Si. dan Bapak Dr. Triyanto Pristiwaluyo, M.Pd. yang telah memberikan arahan serta bimbingan kepada kami hingga dapat menyelesaikan penelitian ini dengan baik.

\section{DAFTAR PUSTAKA}

Arifin, Z. (2012). Penelitian pendidikan: Metode dan paradigma baru. Bandung: Remaja Rosdakarya. Arikunto, S. (2012). Dasar-dasar evaluasi pendidikan (Ed. 2). Jakarta: Bumi Aksara.

Azwar, S. (2015). Reliabilitas dan validitas. Yogyakarta: Pustaka Pelajar.

Bellotti, F., Kapralos, B., Lee, K., Ger, P. M., \& Berta, R. (2013). Assessment in and of serious games: An overview. Advanced in Human-Computer Interaction, 1. doi: 10.1155/2013/136864.

Ebel, R. L \& Frisbie, D.A. (1991). Essentials of educational measurement. New Jersey: Prentice Hall.

Gogri, M.H., Shaikh, S.A., \& Iyengar, V.V. (2013). Evaluation of students performance based on formative assessment using data mining. International Journal of Computer Applications, 67(2), 18-22. Retrieved from: https://pdfs.semanticscholar.org/1b0a/564cf2e92a28511c809 18a819617b093faac.pdf.

Hatziapostolou, T \& Paraskakis, I. (2010). Enhancing the impact of formative feedback on student learning through an online feedback system. Electronic Journal of e-Learning, 8(2), 111-122. Retrieved from: http://www.ejel.org/issue/download.html?idArticle=122.

Kusairi, S. (2012). Analisis asesmen formatif fisika SMA berbantuan komputer. Jurnal Penelitian dan Evaluasi Pendidikan, 16(1), 68-87. doi: https://doi.org/10.21831/pep.v16i0.1106.

Purwanto. (2009). Evaluasi hasil belajar. Yogyakarja: Pustaka Belajar.

Puspendik. (2015). Buku manual UN CBT. Jakarta: Kemdikbud.

Rosyani, P., dkk. (2018). Training to make evaluation of learning media and computer-based exams using Ispring. Proceeding of Community Development, doi: https://doi.org/10.30874/comdev.2018.446.

Sudijono, A. (2015). Pengantar evaluasi pendidikan. Jakarta: Rajawali Pers.

Sudjana, N. (2002). Penilaian hasil proses belajar mengajar. Bandung: Remaja Rosdakarya.

Sugiyono. (2012). Metode penelitian pendidikan pendekatan kuantitatif, kualitatif, dan $R \& D$. Bandung: Alfabeta.

Suratno, J. (2012). Pengembangan sumber belajar interaktif berbasis komputer dengan macromedia flash CS 4. Prosiding Seminar Nasional Pendidikan Matematika, 1(1), 58-71.

Thiagarajan, S., Semmel, D. S., \& Semmel, M. I. (1974). Instructional development for training teacher of exeptional children: A Sourcebook. Bloomington: Indiana University. 